\title{
ETHICAL IDEOLOGIES OF TOURISM MARKETERS
}

\author{
H. Ruhi Yaman \\ Victoria University, Australia \\ Eda Gurel \\ Bilkent University, Turkey
}

\begin{abstract}
This article reports on the findings of the first phase of a wide-ranging study that aims to determine whether tourism managers from different cultures differ in ethical decisionmaking. It examines the ethical ideologies and perceptions of social responsibility of those in charge of organizations operating within the systems in Australia and Turkey. A mail survey was undertaken with a sample of marketing executives of tourism organizations in these countries. Respondents were queried about their ethical ideologies and perceptions of social responsibility and the influence of those on organizational effectiveness. The variation is explained by cultural differences and selected demographic characteristics of the executives and their organizations. Keywords: ethics, social responsibility, moral philosophies, cross-cultural studies. Crown Copyright $\Subset 2006$ Published by Elsevier Ltd. All rights reserved.
\end{abstract}

Résumé: Idéologies éthiques des marketeurs du tourisme. Cet article présente les résultats d'une première étape d'une étude pour déterminer si les directeurs de tourisme de cultures différentes diffèrent dans leur prise de décisions éthiques. Il examine les idéologies éthiques et les perceptions de la responsabilité sociale des responsables des organisations opérant dans les systèmes en Australie et en Turquie. On a entrepris un sondage par courrier avec un échantillon de directeurs de marketing des organisations de tourisme de ces deux pays. On les a interrogés au sujet de leur idéologie éthique et leurs perceptions de la responsabilité sociale et l'influence de ces questions sur l'efficacité de l'organisation. La variation s'explique par les différences culturelles et certaines caractéristiques démographiques des directeurs et des organisations. Mots-clés: éthique, responsabilité sociale, philosophies morales, études interculturelles. Crown Copyright (C) 2006 Published by Elsevier Ltd. All rights reserved.

\section{INTRODUCTION}

Ethics is defined as an "inquiry into the nature and grounds of morality where morality means moral judgments, standards, and rules of conduct" (Tsalikis and Fritzsche 1989:696). From this, "marketing ethics" is defined as "an inquiry into the nature and grounds of moral judgments, standard, and rules of conduct relating to marketing decisions and marketing situations" (Vitell 1986 quoted in Tsalikis and

Ruhi Yaman is Senior Lecturer at the School of Hospitality, Tourism and Marketing of Victoria University (Melbourne, Australia. Email <ruhi.yaman@vu.edu.au>). He was a senior manager in upscale hotels before he joined academe in 1994. His research interests include tourism ethics and destination marketing. Eda Gurel is Instructor at the School of Applied Technology and Management, Bilkent University. Her research interests include tourism ethics and public relations in services. 
Fritzsche 1989:696). These authors note that the term "ethics" is interchangeably used with "morals".

On the other hand, ethics are also tied closely to social responsibility (Hunt, Kiecker and Chonko 1990). Although these concepts are closely related, they should be considered as separate constructs. According to an interpretation of Robin and Reidenbach (1987), "while ethics concerns the rules and standards of conduct related to rules of moral philosophy, social responsibility concerns the social contract existing between business and the society in which it operates" (Hunt et al 1990:240). The nature of this social contract between business and society has been argued by several authorities. For example, Friedman states that "there is one and only one social responsibility of business-to use its resources and engage in activities designed to increase its profits so long as it stays within the rules of the game, which is to say, engages in open and free competition without deception or fraud" (1998:251); he thus acknowledges the economic and legal responsibilities of organizations. Conversely, Spencer and Butler (1987) state that there are definitions which imply that organizations have responsibilities beyond the firm's economic and legal interests.

Although a number of studies have been published on this subject, "the investigation of the ethical aspects of tourism is at a relatively early stage" (Fennell and Malloy 1999:940) and the foundation of research carried out in tourism ethics is very weak (Holden 2003). Nevertheless, the extant literature can be categorized into six groups based on the concepts investigated. The first group consists of works on the ethical challenges surrounding the industry. They attempt to define the issues in tourism (Dunfee and Black 1996; Enghagen and Hott 1992). Upchurch and Ruhland $(1995,1996)$ state that these studies aim to understand the variety of issues that managers and employees come across during their daily operations and consequently to heighten the level of industry awareness of the dilemmas at hand. Other authors (Coughlan 2001; Holden 2003; Payne and Dimanche 1996; Stevens 2001; Wheeler 1995; Whitney 1990) point to the fact that by its very nature, the industry is open to unethical practices. These include sexual harassment, theft, misleading information in menus and brochures, overbooking, and the harm done to natural resources and communities.

The concerns related to development and planning have also attracted the attention of some researchers (Fleckenstein and Huebsch 1999; Holden 2003; Lea 1993). These studies provide a bridge from operational concerns to those that deal with the larger environmental and social issues. Those researchers who fall into the second group are mainly concerned with the negative impacts of tourism on the environment and on communities. The third group argues about the ethical nature of the new types of tourism that have been offered by marketers to offset its negative impacts (Holden 2003, Wheeler 1995, and Wight 1993). Labels such as ecotourism, sustainable, nature, responsible, soft, alternative, and green tourism, (Holden 2003; Wheeler 1995) are thought to reflect attempts at exploitation rather than a genuine concern about its effects on the environment. Wight (1993) states that consumers' growing interest in such areas presents an opportunity to "sell", 
hence to be exploited. He emphasizes that responsible marketing is needed so that both companies and communities can benefit. Walle states that "tourism is not a generic industry since it uniquely impacts on the environment, society and cultural systems in ways which require a holistic orientation within a broad and multidimensional context" (1995:266); "macromarketing" is offered as the solution. Thus, overall the third group of articles concentrates on marketing related issues.

The fourth literature segment deals with codes of ethics in the industry. As Dean (1992:285) indicates, "codes are meant to translate the more formal philosophical theories into a set of guidelines that can be applied to the day to day decision making". Coughlan (2001) asserts that there is a great deal of inquiry on codes in tourism. Some researchers working on codes concentrate on ecotourism and sustainable economic development (D'Amore 1993; Wight 1993). Others (Fleckenstein and Huebsch 1999; Payne and Dimanche 1996) focus on the development of codes and outline the critical values that must be included. Malloy and Fennell (1998) and Stevens (1997) analyze the content of a number of codes of ethics. Coughlan (2001:156) analyzes professional codes in the hospitality industry and finds that "great variation exists between the codes guiding meeting planners and codes guiding salespeople". Malloy and Fennell (1998) point out that there is no research showing the effectiveness of codes. Although some (D'Amore 1993, Wight 1993) claim that a general code of ethics is required in the industry, others question whether developing such a universal code is possible, given cultural differences and the size of the industry (Fleckenstein and Huebsch 1999; Payne and Dimanche 1996). Further, Hultsman (1995) makes a distinction between a paradigmatic ethic and an operational code of ethics, and proposes a framework conceptualized as "just tourism". He argues that "an ethical paradigm for tourism can provide a basis for professional behavior and the development of codes of ethics for service delivery"; he further adds that "the logical starting point for imparting a foundational ethic of tourism services is in the education of tourism students" (1995:561-562).

The fifth group concentrates on the place of ethics in tourism education. The study of Enghagen (1990) shows that the course content of most of the undergraduate programs offered by the Council of Hotel, Restaurant and Institutional Education (CHRIE) include ethics. There seems to be a consensus among scholars to include the subject in professional curricula (Hegarty 1990; Hultsman 1995; Yeung, Wong and Chan 2002:183).

The final group of articles deals with decisionmaking. Studies have been conducted to determine the responses of managers, employees, and students to ethical situations (Damitio and Schmidgall 1993; Stevens 2001; Stevens and Fleckenstein 1999; Wong 1998; Yeung et al 2002); the moral philosophies of managers (Fennell and Malloy 1999; Whitney 1990); and the ethical work climates in lodging operations (Upchurch 1998a,b; Upchurch and Ruhland 1995, 1996). These authors emphasize the importance of the philosophical orientations of managers when they are deciding on an ethical issue (Upchurch 1998a,b; Upchurch and Ruhland 1995, 1996; Whitney 1990). However, 
there is a notable lack of research about the theoretical foundations on which managers base their decisions. As Fennell and Malloy (1999:940) state "the study of the ethical orientations of managers and other stakeholders in tourism is virtually untapped".

The current study falls into the last group. Its purpose is to investigate the perceptions of ethics and social responsibility and ethical orientations of tourism marketing managers. The study is part of an ongoing research project with wider aims. Specifically, this paper presents the comparative findings in Turkish and Australian surveys. These two countries were selected because they fall into different culture clusters in the map proposed by Ronen and Shenkar (1985). The work of these authors reviews and synthesizes the eight available empirical studies in the literature (including the cultural typology of Hofstede 1980) on clustering countries. A "culture cluster" groups countries based on their similarity according to relevant organizational variables. Coombs, Holladay, Hasenauer and Signitzer state that "the examination of countries from different culture clusters is more comparative because of the greater possibility that the countries will be different and not merely the repetition of a similar culture" (1994:26).

\section{ETHICS AND SOCIAL RESPONSIBILITY}

The literature often emphasizes the importance of culture. Payne and Dimanche (1996) argue that there are a number of factors to consider while making ethical, successful business decisions globally, and that culture may have a disproportionate impact. Fleckenstein and Huebsch (1999:140) list cultural differences as one of the five top issues in international tourism. Stevens points out that "cultural differences often create vast discrepancies in perceiving ethical situations" (2001:240). In addition, Walle says "tourism and related disciplines emphasize that cultural differences are real and lasting" (1995:265). This study addresses the need for a cross-cultural investigation of ethics and social responsibility to determine whether managers from different cultures differ in decisionmaking.

\section{Perceived Role of Ethics and Social Responsibility}

"The marketers must first perceive ethics and social responsibility to be important or beneficial to organizational effectiveness before their behaviors will become more ethical and reflect greater social responsibility" (Singhapakdi, Scott and Rallapalli 1995:50). Singhapakdi, Marta, Rao and Curtis (2001b) further argue that an individual's perception about whether ethics and social responsibility are important in achieving organizational effectiveness is also the prerequisite to perceiving that an ethical problem exists. Various empirical research findings support the argument above (Honeycutt, Glassman, Zugelder, and Karander 2001; Rao and Singhapakdi 1997; Singhapakdi et al 1995; Singhapakdi et al 2001b). 


\section{Moral Philosophies}

As Singhapakdi et al state, "Moral philosophy is the foundation upon which the study of ethics rests", and "it is impossible to develop a framework of ethical decisionmaking without evaluating normative ethical standards derived from moral philosophy" (2001b:58). In general, philosophers classify moral philosophies under two main headings, teleology, and deontology (Barnett, Bass, and Brown 1994; Ferrell and Gresham 1985, Forsyth 1992; Hunt and Vitell 1986; Murphy and Laczniak 1981). Hunt and Vitell place these two strands of moral theory at the core of their marketing ethics model: "Deontological theories focus on the specific actions or behaviors of an individual, whereas teleological theories focus on the consequences of the actions or behaviors" (1986:6-7). In other words, the key issue in deontological theories is the inherent goodness and badness or rightness and wrongness of an action, whereas teleological theories concentrate on the degree of goodness or badness embodied in the consequences of the action.

Forsyth (1980) proposes that there are two basic dimensions of personal moral philosophy, idealism and relativism; the differences in ideology can be described by these two dimensions. He defines relativism as "the extent to which the individual rejects universal moral rules", whereas idealistic individuals "assume that desirable consequences can, with the 'right' action, always be obtained" (1980:175-176). Accordingly, idealistic individuals tend to make use of moral absolutes when making judgments and believe that morally "right" behavior always leads to positive and desirable consequences. On the other hand, relativistic individuals tend to reject universal moral rules and believe that undesirable consequences will often be mixed in with desired ones.

When the idealism and relativism dimensions are dichotomized and crossed, Forsyth's (1980) taxonomy can identify four distinct personal moral philosophies. Individuals can be classified as situationists (relativistic and idealistic_-having high relativism and idealism values), subjectivists (relativistic but not idealistic-having high relativism but low idealism values), absolutists (not relativistic but idealistic-having low relativism but high idealism values), and exceptionists (neither relativistic nor idealistic - having low relativism and idealism values). He states these four moral philosophies can be compared to specific schools of thought. The absolutist tendency to judge actions as moral or immoral against some universal moral rule is consistent with a general approach to moral philosophy known as deontology; the exceptionist tendency to act in a way that produces "good" consequences is consistent with a teleological philosophy. This approach is best represented by the utilitarian concept of the greatest good for the greatest number.

\section{Culture and Ethical Decisionmaking}

As proposed by Singhapakdi, Karande, Rao, Scott (2001a), variations in the perceived importance of ethics and social responsibility as determinants of organizational effectiveness can be explained by country differences (including cultural differences and differences in the 
economic environment), as well as by organizational climate, and individual characteristics of gender and age. Various other researchers have also mentioned the potential influence of culture on business ethics (Ferrell and Grasham 1985; Hunt, Wood, and Chonko 1989; Vitell, Nwachukwu, and Barnes 1993b).

Hofstede defines culture as "the collective programming of the mind which distinguishes the members of one category of people from those of another" and suggests four dimensions to explain behavioral differences among individuals from different nations. His four cultural dimensions are power distance, individualism, masculinity, and uncertainty avoidance. Power distance refers to "the extent to which the less powerful person in a society accepts inequality in power and considers it as normal'".

Individualist cultures oppose collectivist ones in which individuals belong to one or more close "in-groups" and feel themselves not connected to those that are outside their immediate circle. On the other hand, in individualistic cultures, individuals are primarily concerned with their own and immediate family interests. Masculine cultures define very different sex roles for men and women. In societies with high masculinity, men are expected to be assertive, ambitious, and competitive to gain material success, whereas women are expected to serve and to care for the nonmaterial quality of life-for children, and for the weak. In contrast, feminine cultures support relatively overlapping social roles for the sexes. Uncertainty avoidance refers to the extent to which people within a culture are made nervous by ambiguous situations and the extent to which they seek to adopt strict codes of behavior to avoid those situations. Cultures with high uncertainty avoidance are security-seeking and intolerant whereas cultures with low uncertainty avoidance are accepting of personal risk and relatively tolerant (1984:389-390).

According to Hofstede's $(1983,1984)$ typology, Turkey is low in individualism (24th among 50 countries), has large power distance, and is a relatively masculine culture with strong uncertainty avoidance. Australia, on the other hand, displays rather different cultural characteristics. It is a highly individualistic country (rating second after the United States), with relatively more feminine tendencies, smaller power distance, and weaker uncertainty avoidance.

Hofstede's typology has been used in several studies investigating ethical decisionmaking in different cultural groups (Beekun, Stedham, and Yamamura 2003; Singhapakdi, Rallapalli, Rao and Vitell 1993). Study results show significant differences of ethical orientation among the cultures that are dissimilar according to Hofstede's cultural typology. The study by Singhapakdi et al (2001b), which investigates the ethical orientations of American and Australian managers, indicates that similar cultures may not necessarily have similar orientations.

Referring to the works of Forsyth (1980) and Hofstede (1983, 1984), the following hypotheses may be stated:

H1a: Turkish tourism marketers are more idealistic than Australian marketers.

H1b: Turkish marketers are less relativistic than Australian marketers. 
H1c: The perceived importance of ethics and social responsibility between the two groups will differ because of the cultural dissimilarities.

H1d: Regardless of culture, idealistic marketers are more likely to have a higher perception of the importance of ethics than their relativistic counterparts.

H1e: Regardless of culture, relativistic tourism marketers are less likely to have a higher perception of the importance of ethics than their idealistic counterparts.

\section{Gender}

Although gender is one of the most frequently studied variables, the results show contradictory findings. For example, in some studies women are found to be more ethically sensitive than men (Deshpande, Joseph and Masimow 2000; Ekin and Tezölmez 1999; Kelly, Ferrell and Skinner 1990; Lewicki and Robertson 1998; Luthar, DiBattista, and Gautschi 1997). Tsalikis and Fritzsche (1989) report that in his series studies for the Wall Street Journal, Ricklefs found that women consistently behave more ethically than men. Chonko and Hunt (1985) report that female marketing managers are more sensitive to ethical problems than males. Similarly, Akaah (1989) reports that these professionals have higher ethical judgments than their male counterparts.

Contrary to the above, some studies show no significant differences in the beliefs of female and male managers (Callan, 1992; Davis and Welton 1991; Fritzsche 1988; Nyaw and Ng 1994; Singhapakdi and Vitell 1990). However, as Collins (2000) notes, none of the studies show men demonstrating more sensitivity to ethical issues than women. Therefore:

H2a: Regardless of culture, female marketers are more idealistic than males.

H2b: Regardless of culture, female marketers are less relativistic than males.

H2c: Regardless of culture, female marketers perceive ethics to be more important for organizational effectiveness than do male marketers.

\section{Level of Education}

Research findings on educational level and ethical beliefs are also mixed. Lund (2000) reports that this factor significantly influences a marketing professional's moral behavior. The study of Browning and Zabriskie (1983) shows that purchasing managers with more education view vendor gifts and favors to be more unethical than less educated purchasing managers. However, in the studies of Dubinsky and Ingram (1984), Kidwell, Stevens, and Bethke (1987) and Serwinek (1992), no significant relationship between the individual's years of education and ethical beliefs was found. In addition, Honeycutt et al (2001) who propose a model to explain the behavior of automobile salespeople, claim that education is not significantly related to moral behavior. Moreover, Merritt (1991) reports that level of education did not influence ethical sensitivities.

On the other hand, Ho, Vitell, Barnes and Desborde's (1997) study which examines the relationship between the educational level and 
moral philosophies of marketers shows that there is a negative relationship between education and idealism. Therefore:

H3a: Regardless of culture, more educated managers are less idealistic than less educated managers.

H3b: Regardless of culture, more educated managers are more relativistic than less educated managers.

\section{Size of Organization}

Empirical research findings indicate that there is a relationship between organization size and moral judgment of the managers (Ford and Richardson 1994). For example, the research conducted by Browning and Zabriskie (1983) shows that managers in larger firms are more likely to accept gifts from former suppliers. Similarly, Dalton and Kesner (1988) report those managers are also more likely to engage in unethical behavior than the managers of small organizations. However, Schminke (2001), in his study of the relationship between organization size, structure, and the strength of the members' predispositions, finds that larger organizations with more rigid and mechanical structures have higher levels of ethical formalism and utilitarianism than smaller organizations with more flexible and organic structures. Similarly, the study conducted by Stanwick and Stanwick (1998:198) shows a firm's corporate social performance is positively influenced by the size of the firm. Therefore:

H4: Regardless of culture, marketers in larger organizations will differ from those in smaller ones in their perception of the importance of ethics for organizational effectiveness.

\section{Study Method}

A self-administered questionnaire was used to collect data from both Australian and Turkish marketers. The sample for the Australian marketers came from a survey of the largest service organizations operating within the various tourism sectors in Australia. As there was no single list of all enterprises operating within the tourism system, a combination of judgmental and snowball-sampling techniques was used to identify the organizations. A database of 160 leading bodies was compiled by personally contacting each organization by telephone to obtain the name and the title of the person in charge of marketing operations. A copy of the questionnaire was forwarded to the person identified, followed by a telephone call after ten days to remind the recipients who had not yet responded. A total of 78 completed questionnaires was received. To obtain the highest possible response rate, each of the respondents was telephoned and asked to nominate two organizations outside his or her own which should have been included in the list. Ultimately, 62 respondents nominated a total of 124 organizations that were not in the original sample. After checking against the criteria, 109 organizations were selected as suitable to add to the original database, increasing 
the total sample to 269. A new mail-out was organized for 109 entities using the same questionnaire. Twenty-three usable questionnaires were obtained as a result. The total response was 101, representing a $37 \%$ response rate on the final sample of 269 organizations.

In the case of Turkey, the directories of the Ministry of Tourism and the Association of Turkish Travel Agencies, as well as sources of the Ministry of Culture formed the initial sampling frame of 1,000 tourism marketers. The sample was chosen by utilizing a "judgmental sampling method" that included the major players in the Turkish tourism and hospitality industry, as in the Australian phase of the study.

Each of the 1,000 marketers received the questionnaire, a cover letter (which emphasized the international nature of the study and promised a copy of the study results), and a pre-addressed return envelope. Additional efforts, such as personal presentations to industry associations, were expended to increase the response rate. Ultimately, a total of 219 questionnaires were received from the overall number of 1,066, for a $20.5 \%$ response rate. A detailed profile of both groups of respondents is presented in Table 1.

The instrument used in the Australian phase of the study was in English. It was translated into Turkish by the Translation and Interpretation Department of Bilkent University, Turkey. In order to test the accuracy of the translated instrument, a pretest was conducted using 12 academics and industry practitioners. Based on the results of the pretest, changes were made in the wording of some of the items. For example, Turkish use of the terms "moral" and "ethics" might lead to confusion as a result of a lack of distinction between the two; therefore, all items with the word etik (ethics) were changed to the word ahlak (moral). The Turkish version of the instrument was tested again with five different academics and after further 'fine-tuning', it was ensured that the final version of the instrument was as close as possible to the original used in the Australian phase of the study.

$T$-tests were conducted on three demographic variables to compare Turkish and Australian marketers; the variables tested were gender, position in the organization, and level of education. Results indicated that there were no significant differences between the two groups on any of the three variables tested.

In this study, the ethics position questionnaire developed by Forsyth (1980) was used to measure the moral ideologies of the marketers. A 5point continuous scale was adopted (Vitell, Rallapalli, and Singhapakdi 1993a) in place of the original 9-point scale. For each respondent, two scores were computed by taking the mean score of their responses to the idealism and relativism items respectively. Reliability assessments for both dimensions were conducted for the purposes of this study. The Cronbach's coefficient alpha values for idealism and relativism scales were 0.84 and 0.79 , respectively. The scale has been used in a number of studies to examine the influence of individual differences in idealism and relativism on a number of variables from moral and ethical judgments in business to perceived moral intensity (Barnett et al 1994; Chonko, Wotruba and Loe 2003; Deering 1998; Eastman, Eastman and Tolson 2001; Elias 2002; Vitell et al 1993a). 
Table 1. Characteristics of the Sample

\begin{tabular}{|c|c|c|c|c|}
\hline \multirow{2}{*}{$\begin{array}{l}\text { Group Profiles } \\
\text { Characteristics }\end{array}$} & \multicolumn{2}{|c|}{ Turkey } & \multicolumn{2}{|c|}{ Australia } \\
\hline & Frequency & Percentage & Frequency & Percentage \\
\hline \multicolumn{5}{|l|}{ Individual characteristics } \\
\hline \multicolumn{5}{|l|}{ Gender } \\
\hline Female & 55 & 25.5 & 36 & 35.6 \\
\hline Male & 161 & 74.5 & 65 & 64.4 \\
\hline \multicolumn{5}{|l|}{ Educational level } \\
\hline Secondary school & 28 & 13.2 & 11 & 10.9 \\
\hline Associate diploma & 22 & 10.4 & 10 & 9.9 \\
\hline Bachelor's degree & 127 & 59.9 & 38 & 37.6 \\
\hline Postgraduate degree & 35 & 16.5 & 42 & 41.6 \\
\hline \multicolumn{5}{|l|}{ Area of specialization } \\
\hline Business (Hospitality \& Tourism) & 118 & 55.7 & 37 & 36.6 \\
\hline Business (other than $\mathrm{H} \& \mathrm{~T}$ ) & 32 & 15.1 & 34 & 33.7 \\
\hline Arts/Humanities & 38 & 17.9 & 13 & 16.8 \\
\hline Other & 24 & 7.1 & 17 & 12.9 \\
\hline \multicolumn{5}{|l|}{ Position } \\
\hline Owner/operator & 56 & 27.2 & 3 & 3.0 \\
\hline Managing director/CEO & 40 & 19.4 & 4 & 4.0 \\
\hline General manager & 23 & 11.2 & 9 & 8.9 \\
\hline Senior manager & 87 & 53.5 & 85 & 84.2 \\
\hline \multicolumn{5}{|l|}{ Organizational characteristics } \\
\hline \multicolumn{5}{|l|}{ Organizational annual revenue ${ }^{a}$} \\
\hline Under $\$ 1 \mathrm{~m}$ & 60 & 37.7 & 13 & 12.9 \\
\hline$\$ 1$ to $\$ 4.9 \mathrm{~m}$ & 36 & 22.6 & 8 & 7.9 \\
\hline$\$ 5$ to $\$ 24.9 \mathrm{~m}$ & 39 & 24.5 & 25 & 24.8 \\
\hline$\$ 25 \mathrm{~m}$ and over & 12 & 7.5 & 50 & 49.5 \\
\hline \multicolumn{5}{|l|}{ Foundation date } \\
\hline 1970 or before & 31 & 15.5 & 21 & 20.8 \\
\hline $1971-1980$ & 22 & 10.8 & 4 & 4.0 \\
\hline $1981-1990$ & 58 & 28.9 & 4 & 4.0 \\
\hline 1991 or later & 90 & 44.8 & 72 & 71.2 \\
\hline \multicolumn{5}{|l|}{ Number of employees } \\
\hline$<10$ & 45 & 22.1 & 6 & 5.9 \\
\hline $10-19$ & 33 & 16.2 & 9 & 8.9 \\
\hline $20-49$ & 42 & 20.6 & 14 & 13.9 \\
\hline $50>$ & 84 & 41.2 & 72 & 71.3 \\
\hline \multicolumn{5}{|l|}{ Sector } \\
\hline Hospitality (with food \& beverage) & 78 & 35.8 & 32 & 31.7 \\
\hline Food & 20 & 9.2 & 15 & 14.9 \\
\hline Travel (travel agency) & 38 & 17.4 & 13 & 12.9 \\
\hline Travel (transport) & 19 & 8.7 & 5 & 4.9 \\
\hline Industry support organization & 4 & 1.8 & 8 & 7.9 \\
\hline Attraction & 34 & 15.6 & 14 & 13.9 \\
\hline Event organization & 8 & 3.7 & 5 & 4.9 \\
\hline Association (national) & 11 & 5.0 & 2 & 2.0 \\
\hline Association (regional) & 3 & 1.4 & 5 & 4.9 \\
\hline Other & 3 & 1.4 & 2 & 2.0 \\
\hline
\end{tabular}

At the time of study, 1 US $\$=1.625 \mathrm{TL}$.

${ }^{a}$ Converted from Turkish Lira to US Dollar. 
To measure managers' perceptions about the importance of ethics and social responsibility in organizational effectiveness, this study used the perceived role of ethics and social responsibility (PRESOR) scale, developed by Singhapakdi et al (1995) This instrument has been used in various studies; some of them cross-cultural (Etheredge 1999; Singhapakdi et al 2001a; Elias 2002).

As pointed out by Etheredge (1999), studies utilizing the instrument in cultures other than American, suggest a two-factor structure rather than three. Likewise in this study, the combined Turkish and Australian data supported a two-factor structure with 15 items. This conclusion was reached after the 16 items were analyzed using the principal components analysis. The scree plot indicated that the initial assumption of multidimensionality was correct. A three-factor solution accounted for $47.9 \%$ of the variance, and a two-factor solution accounted for $38.7 \%$ of the variance. Consequently, both solutions were rotated using a Varimax rotation procedure. The rotation did not show any identifiable resemblance to the three-factor solution obtained by Singhapakdi, Vitell, Rallapalli and Kraft (1996). There were no split-loading problems in the two-factor structure and it made better conceptual sense. The Kaiser-Meyer-Olkin measure of sampling adequacy was 0.81 . The results of the factor analysis for two factors can be seen in Table 2 .

Etheredge's (1999) labels were used for this study. The first factor, consisting of seven items, was labeled "importance of ethics and social responsibility"; it expresses the importance of ethics and social responsibility both in principle and for the effectiveness of the organization. The second factor, consisting of eight items, was labeled "subordination of ethics and social responsibility" and reflects the concept that ethics and social responsibility may at best be supplementary to profitability and survival of the organization.

\section{Study Findings}

A univariate analysis of variance was used to test the hypotheses H1a, $\mathrm{H} 1 \mathrm{~b}$, and H1c. Turkish managers were significantly more idealistic and more relativistic than Australian managers $(F=36.63, p=0.00)$. The small score of standard deviation on idealism in the case of the Turkish group (.51) indicates uniformity in the views of the group (homogeneity). The standard deviation for relativism, on the other hand, was very high (.89) indicating a lack of homogeneity in the group. Although the higher relativism score was unexpected in this survey, it is in accordance with the previous research comparing managers from collectivist cultures to those from individualistic cultures (Singhapakdi, Vitell and Leelakulthanit 1994). Turkish managers had a higher perception of the importance of ethics and social responsibility for organizational effectiveness.

Regression analyses were performed using the PRESOR1 (importance of ethics to organizational effectiveness) item as the dependent variable; idealism, relativism, gender, education, and the size of the organization were the independent variables to test hypotheses 2, 3 
Table 2. Exploratory Factor Analysis of the PRESOR Instrument

\begin{tabular}{|c|c|c|c|}
\hline No. & Item & Factor 1 & Factor 2 \\
\hline 1 & $\begin{array}{c}\text { Being ethical and responsible is the most important } \\
\text { thing a firm can do }\end{array}$ & .738 & \\
\hline 4 & $\begin{array}{l}\text { Corporate planning and goal setting sessions should } \\
\text { include discussions of ethics and social responsibility }\end{array}$ & .421 & \\
\hline 6 & $\begin{array}{l}\text { The ethics and social responsibility of an organization } \\
\text { is essential to its long term profitability }\end{array}$ & .675 & \\
\hline 7 & $\begin{array}{l}\text { The overall effectiveness of a business can be determined } \\
\text { to a great extent by the degree to which it is ethical } \\
\text { and socially responsible }\end{array}$ & .706 & \\
\hline 10 & $\begin{array}{c}\text { Business ethics and social responsibility are critical to the } \\
\text { survival of a business enterprise }\end{array}$ & .682 & \\
\hline 11 & An organization's first priority should be employee morale & .663 & \\
\hline 14 & $\begin{array}{c}\text { Efficiency is much more important to an organization } \\
\text { than whether or not the organization is seen as ethical } \\
\text { or socially responsible }\end{array}$ & .534 & \\
\hline 15 & Good ethics is often good business & .472 & \\
\hline 5 & $\begin{array}{l}\text { The most important concern for an organization is making } \\
\text { a profit, even if it means bending or breaking the rules }\end{array}$ & & .694 \\
\hline 2 & $\begin{array}{l}\text { While output quality is essential to corporate success, ethics } \\
\text { and social responsibility is not }\end{array}$ & & .594 \\
\hline 8 & $\begin{array}{c}\text { To remain competitive in a global environment, business } \\
\text { organizations will have to disregard } \\
\text { ethics and social responsibility }\end{array}$ & & .671 \\
\hline 9 & Social responsibility and profitability can be compatible & & -.404 \\
\hline 12 & Business has a social responsibility beyond making a profit & & -.425 \\
\hline 13 & $\begin{array}{l}\text { If survival of business enterprise is at stake, then you } \\
\text { must forget about ethics and social responsibility }\end{array}$ & & .648 \\
\hline 16 & If the shareholders are unhappy, nothing else matters & & .543 \\
\hline
\end{tabular}

and 4; idealism was the dependent variable to test the rest of the hypotheses. The correlation matrix of dependent and independent variables is presented in Table 3 . The assumption of homoscedasticity is not violated, as the application of Levene's test of equality of error variances did not result in the rejection of the null hypotheses of equal variances across groups (.01 level) for any of the variables tested. The maximum variance inflation factor $(\mathrm{VIF})$ was 2.842 (tolerance $=.352$ ), thus assuring that there were no problems of multicollinearity among the independent variables (below the acceptable level of 10 suggested by Neter, Wasserman and Kutne 1989).

H1d and H1e state that idealistic tourism marketers are more likely to have a higher perception of the importance of ethics and social responsibility than their relativistic counterparts, where relativistic marketers are more likely to have a lower perception of the same. These hypotheses are supported; idealism appears as a significant determinant of PRESOR1 by an examination of the standardized beta from the regression analysis $(0.329, p=.000)$, where relativism is 
Table 3. Moral Dimensions of Turkish and Australian Managers

\begin{tabular}{|c|c|c|c|c|c|c|c|}
\hline $\begin{array}{l}\text { Moral } \\
\text { Dimensions }\end{array}$ & Revenue & Education & Gender & PRESOR1 & PRESOR2 & Idealism & Relativism \\
\hline \multicolumn{8}{|l|}{ Relativism } \\
\hline Idealism & & & & & & & .028 \\
\hline PRESOR2 & & & & & & -.065 & $.271^{\mathrm{b}}$ \\
\hline PRESOR1 & & & & & $-.259^{\mathrm{b}}$ & $.400^{\mathrm{b}}$ & $-.203^{\mathrm{b}}$ \\
\hline Gender & & & & .049 & -.088 & .024 & .060 \\
\hline Education & & & $.166^{\mathrm{b}}$ & -.037 & .000 & $-.142^{\mathrm{a}}$ & $-.125^{\mathrm{a}}$ \\
\hline Revenue & & $.165^{\mathrm{b}}$ & $.130^{\mathrm{a}}$ & $-.265^{\mathrm{b}}$ & .019 & -.158 & .004 \\
\hline
\end{tabular}

PRESOR1 = Importance of Ethics to Organizational Effectiveness. PRESOR2 = Subordination of Ethics to Organizational Effectiveness. ${ }^{a}$ Correlation is significant at the 0.05 level (2-tailed). ${ }^{\mathrm{b}}$ Correlation is significant at the 0.01 level (2-tailed).

shown as a significant negative determinant of PRESOR1 $(-0.210$, $p=.000)$.

Gender differences on perceptions of ethics for organizational effectiveness were not significant. There were also no significant differences in idealism and relativism scores between male and female managers. Therefore, H3 was not supported. No significant relationship was found between those managers who had post-secondary and those who had further education in their idealism levels. However, when the variable was grouped into "managers with secondary education only" and "managers with post-secondary or further education" there was a significant relationship between the formal education levels and idealism scores $(t=2.75, p=0.00)$. Managers without the benefit of higher education tended to be more idealistic in their moral philosophies. However, H4 was strongly supported as the analysis linked the size of the organization to PRESOR1 as a negative determinant $(t=-2.33, p=.020)$. This suggests that managers of small enterprises (10 employees or less) tended to have a higher perception of the importance of ethics for organizational effectiveness than those of larger businesses.

\section{CONCLUSION}

Based on the results of this study, Turkish tourism marketers are both more idealistic and more relativistic when compared to their Australian counterparts. The high mean score on the idealism dimension and the moderate mean score on the relativism dimension suggest that according to Forsyth (1980:176), Turkish marketing professionals can be classified as "absolutists" who "tend to agree with statements that are consistent with a general approach to moral philosophy known as deontology" which "rejects the use of an action's consequences as a basis for moral evaluation and appeals to natural law or rationality to determine ethical judgments'. On the other hand, the higher rela- 
tivism score for a factor that included items such as, "ethics vary from one society to another", "moral standards are individualistic", "moralities cannot be compared as to rightness" and "others' morals cannot be judged", may indicate that Turks are tolerant towards the ethical judgment of other people or cultures and believe that personal moral philosophies can change from one culture to another (and/or from one person to another).

The results for the effect of higher education on perception of the importance of ethics for organizational effectiveness invite the sometimes popular notion that higher education, especially in business, makes people more skeptical; this skepticism may be encouraged by promoting power and success as the ultimate goal or by making the students aware of the complexity of the world where there are no easy solutions to difficult problems. However, the essentially exploratory nature of the study can only serve to indicate a need for further investigation into the effect of modern business higher education on the ethical development of managers. Clearly, it is not education in general that makes the difference, but the incorporation of ethics teaching into the curricula (including the manner in which it is incorporated) and how this would impact on the managers' perception of the importance of ethics for organizational effectiveness (Yaman 2003). Both the general educational approach and the inclusion of and emphasis on ethics within the education system are different in the two countries. Future research might investigate the level and manner of inclusion of ethics teaching in higher education, especially in business courses.

Similarly, although lack of any significant findings on the effect of gender differences supports some past studies, this result cannot be considered conclusive. The samples were heavily skewed toward males, reflecting the reality of gender balance in management. Also the relative positions of power held and the educational status of the two genders were not taken into account. A more homogeneous comparison of gender differences might produce different results.

An important implication of the study refers to organizational size. It appears that the larger the organization, the less likely are the managers to consider that ethics and social responsibility are important for the organization. This finding ties in with the one on education as more educated managers are increasingly employed by larger organizations-a reality for both countries under investigation.

Another limitation of this study is the number of factors that are investigated. Ethical decisionmaking is a difficult and elusive phenomenon; cross-cultural differences make it even more complex. Two of the important variables that were not investigated by this study are religion and professional environment. An inclusion of the five dimensions of Hofstede's $(1983,1984)$ cultural taxonomy (power distance, uncertainty avoidance, individualism, and masculinity) would make the investigation more global and generalizable.

In summary, this study stemmed from the conviction that to understand the different management approaches towards ethical issues in the industry, it is important to utilize those normative theories which 
underlie moral decisionmaking. This study is not an attempt to determine what action or which approach is more ethical. Rather, it aims to determine whether tourism marketers from identifiably different cultures vary in their perceptions of ethics and social responsibility, their beliefs in moral philosophies, and their perceptions of the importance of moral and socially responsible decisionmaking. The results show that there are differences in the perceptions and moral philosophies of marketers that can be related to cultural differences. Further research is required to extend the area of inquiry not only by including other distinctly different cultures, but also by increasing the factors that are theorized to have influence in ethical decisionmaking. Consequently, the results may be used to develop and test a conceptual model of antecedents and consequences of the perceived importance of ethics and social responsibility. $\mathbf{A}$

\section{REFERENCES}

Akaah, I.

1989 Differences in Research Ethics Judgments between Male and Female Marketing Professionals. Journal of Business Ethics 8:375-381.

Barnett, T., K. Bass, and G. Brown

1994 Ethical Ideology and Ethical Judgment Regarding Ethical Issues in Business. Journal of Business Ethics 13:469-480.

Beekun, R., Y. Stedham, and J. Yamamura

2003 Business Ethics in Brazil and the US: A Comparative Investigation. Journal of Business Ethics 42:267-279.

Browning, J., and N. Zabriskie

1983 How Ethical are Industrial Buyers? Industrial Marketing Management 12:219-224.

Callan, V.

1992 Predicting Ethical Values and Training Needs in Ethics. Journal of Business Ethics 11:761-769.

Chonko, L., and S. Hunt

1985 Ethics and Marketing Management: An Empirical Investigation. Journal of Business Research 13:339-359.

Chonko, L., T. Wotruba, and T. Loe

2003 Ethics Code Familiarity and Usefulness: Views on Idealist and Relativist Managers Under Varying Conditions of Turbulence. Journal of Business Ethics 42:237-252.

Collins, D.

2000 The Quest to Improve the Human Condition: The First 1500 Articles Published in Journal of Business Ethics 26:1-73.

Coombs, W., S. Holladay, G. Hasenauer, and B. Signitzer

1994 A Comparative Analysis of International Public Relations: Identification and Interpretation of Similarities and Differences between Professionalization in Austria, Norway, and the United States. Journal of Public Relations Research 6(1):23-39.

Coughlan, R.

2001 An Analysis of Professional Codes of Ethics in the Hospitality Industry. Hospitality Management 20:147-162.

Dalton, D., and I. Kesner

1988 On the Dynamics of Corporate Size and Illegal Activity: An Empirical Assessment. Journal of Business Ethics 7:861-870.

Damitio, J., and R. Schmidgall

1993 Hospitality Professionals' Responses to Ethical Situations. Cornell Hotel and Restaurant Administration Quarterly 34(4):40-43. 
D'Amore, L.

1993 A Code of Ethics and Guidelines for Socially and Environmentally

Responsible Tourism. Journal of Travel Research 31(3):64-66.

Davis, J., and R. Welton

1991 Professional Ethics: Business Students' Perceptions. Journal of Business Ethics 10:451-463.

Dean, P.

1992 Making Codes of Ethics “Real”. Journal of Business Ethics 11:285-290.

Deering, $\mathrm{T}$.

1998 The Ethical Perspective of British and American Preservice Teachers. Educational Research 40:353-358.

Deshpande, S., J. Joseph, and V. Masimow

2000 Perceptions of Proper Ethical Conduct of Male and Female Russian Managers. Journal of Business Ethics 24:179-183.

Dubinsky, A., and T. Ingram

1984 Correlates of Salespeople's Ethical Conflict: An Exploratory Investigation. Journal of Business Ethics 3:343-353.

Dunfee, T., and B. Black

1996 Ethical Issues Confronting Travel Agents. Journal of Business Ethics 15:207-217.

Eastman, J., K. Eastman, and M. Tolson

2001 The Relationship between Ethical Ideology and Ethical Behavioral Intentions: An Exploratory Look at Physicians' Responses to Managed Care Dilemmas. Journal of Business Ethics 31:209-224.

Ekin, M., and S. Tezölmez

1999 Business Ethics in Turkey: An Empirical Investigation with Special Emphasis on Gender. Journal of Business Ethics 18:17-34.

Elias, R.

2002 Determinants of Earnings Management Ethics among Accountants. Journal of Business Ethics 40:33-45.

Enghagen, L.

1990 Ethics in Hospitality/Tourism Education: A Survey. Hospitality Research Journal 14:113-118.

Enghagen, L., and D. Hott

1992 Student's Perceptions of Ethical Issues in the Hospitality and Tourism Industry. Hospitality Research Journal 15(2):41-50.

Etheredge, J.

1999 The Perceived Role of Ethics and Social Responsibility: An Alternative Scale Structure. Journal of Business Ethics 18:51-64.

Fennell, D., and D. Malloy

1999 Measuring the Ethical Nature of Tourism Operators. Annals of Tourism Research 26:928-943.

Ferrell, O., and L. Gresham

1985 A Contingency Framework for Understanding Ethical Decision Making in Marketing. Journal of Marketing 49(3):87-96.

Fleckenstein, M., and P. Huebsch

1999 Ethics in Tourism-Reality or Hallucination. Journal of Business Research 19:137-142.

Ford, R., and W. Richardson

1994 Ethical Decision Making: A Review of the Empirical Literature. Journal of Business Ethics 13:205-211.

Forsyth, D.

1980 A Taxonomy of Ethical Ideologies. Journal of Personality and Social Psychology 49:218-223.

1992 Judging the Morality of Business Practices: The Influence of Personal Moral Philosophies. Journal of Business Ethics 11:461-470.

Friedman, M.

1998 The Social Responsibility of Business is to Increase its Profits. In Perspectives in Business Ethics, L. Hartman, ed., pp. 246-251. New York: Irwin McGraw Hill. 
Fritzsche, D.

1988 An Examination of Marketing Ethics: Role of the Decision Maker, Consequences of the Decision, Management Position and Sex of the Respondent. Journal of Macromarketing 8(2):29-39.

Hegarty, J.

1990 Ethics in Hospitality Education. International Journal of Hospitality Management 9:106-109.

Ho, F., S. Vitell, J. Barnes, and R. Desborde

1997 Ethical Correlates of Role Conflict and Ambiguity in Marketing: The Mediating Role of Cognitive Moral Development. Journal of the Academy of Marketing Science 25(2):117-126.

Holden, A.

2003 In Need of New Environmental Ethics for Tourism? Annals of Tourism Research 30:94-108.

Hofstede, G.

1980 Motivation, Leadership and Organization: Do American Theories Apply Abroad? Organizational Dynamics 9(1):42-63.

1983 National Cultures in Four Dimensions: A Research-based Theory of Cultural Differences among Nations. International Studies of Management and Organization 13(1-2):46-74.

1984 The Cultural Relativity of the Quality of Life Concept. Academy of Management Review 9:389-398.

Honeycutt, E., M. Glassman, M. Zugelder, and K. Karander

2001 Determinants of Ethical Behavior: A Study of Autosalespeople. Journal of Business Ethics 32:69-79.

Hultsman, J.

1995 Just Tourism: An Ethical Framework. Annals of Tourism Research 22:553-567.

Hunt, S., and S. Vitell

1986 A General Theory of Marketing Ethics. Journal of Macromarketing $8(1): 5-16$

Hunt, S., V. Wood, and L. Chonko

1989 Corporate Ethical Values and Organizational Commitment in Marketing. Journal of Marketing 53:79-90.

Hunt, S., P. Kiecker, and L. Chonko

1990 Social Responsibility and Personal Success: A Research Note. Journal of Academy of Marketing Science 18:239-244.

Kelly, S., O. Ferrell, and S. Skinner

1990 Ethical Behavior Among Marketing Researchers: An Assessment of Selected Demographic Characteristics. Journal of Business Ethics 9:681688.

Kidwell, J., R. Stewens, and A. Bethke

1987 Differences in Ethical Perceptions between Male and Female Managers: Lea, J. Myth or Reality? Journal of Business Ethics 6:489-493.

1993 Tourism Development Ethics in the Third World. Annals of Tourism Research 20:701-715.

Lewicki, R., and R. Robertson

1998 Ethical and Unethical Bargaining Tactics: An Empirical Study. Journal of Business Ethics 17:665-682.

Lund, D.

2000 An Empirical Examination of Marketing Professionals' Ethical Behavior in Differing Situations. Journal of Business Ethics 24:331-342.

Luthar, H., R. DiBattista, and T. Gautschi

1997 Perception of What the Ethical Climate is and What it Should Be: The Role of Gender, Academic Status, and Ethical Education. Journal of Business Ethics 16:205-217.

Malloy, D., and D. Fennel

1998 Codes of Ethics and Tourism: An Exploratory Content Analysis. Tourism Management 19:453-461. 
Merritt, S.

1991 Marketing Ethics and Education: Some Empirical Findings. Journal of Business Ethics 10:625-632.

Murphy, P., and G. Laczniak

1981 Marketing Ethics: A Review with Implications for Marketers, Educators and Researchers. In Review of Marketing, B. M. Enis and K. Roeing, eds., pp. 13-25. Chicago: American Marketing Association.

Neter, J., W. Wasserman, and M. Kutne

1989 Applied Linear Regression Models. Homewood: Irwin Press.

Nyaw, M., and I. Ng

1994 A Comparative Analysis of Ethical Beliefs: A Four Country Study. Journal of Business Ethics 13:543-555.

Payne, D., and F. Dimanche

1996 Towards a Code of Conduct for the Tourism Industry: An Ethics Model. Journal of Business Ethics 15:997-1007.

Rao, C., and A. Singhapakdi

1997 Marketing Ethics: A Comparison between Services and Other Marketing Professionals. Journal of Services Marketing 11:409-426.

Robin, D., and R. E. Reidenbach

1987 Social Responsibility, Ethics and Marketing Strategy: Closing the Gap Between Concept and Application. Journal of Marketing 51:44-58.

Ronen, S., and O. Shenkar

1985 Clustering Countries on Attitudinal Dimensions: A Review and Synthesis. Academy of Management Review 10:435-454.

Schminke, M.

2001 Considering the Business in Business Ethics: An Exploratory Study of the Influence of Organizational Size and Structure on Individual Ethical Predispositions. Journal of Business Ethics 30:375-390.

Serwinek, $\mathrm{P}$.

1992 Demographic and Related Differences in Ethical Views Among Small Businesses. Journal of Business Ethics 11:555-566.

Singhapakdi, A., and S. Vitell

1990 Marketing Ethics: Factors Influencing Perceptions of Ethical Problems and Alternatives. Journal of Macromarketing 10(1):4-18.

Singhapakdi, A., K. Rallapalli, C. Rao, and S. Vitell

1993 Personal and Professional Values Underlying Ethical Decisions: A Comparison of American and Thai Marketers. International Marketing Review $12(4): 63-76$.

Singhapakdi, A., S. Vitell, and O. Leelakulthanit

1994 A Cross-cultural Study of Moral Philosophies, Ethical Perceptions and Judgments: A Comparison of American and Thai Marketers. Journal of Marketing Review 11(6):65-78.

Singhapakdi, A., S. Scott, and K. Rallapalli

1995 The Perceived Importance of Ethics and Social Responsibility on Organizational Effectiveness: A Survey of Marketers. Journal of the Academy of Marketing Science 23(1):49-56.

Singhapakdi, A., S. Vitell, K. Rallapalli, and K. Kraft

1996 The Perceived Role of Ethics and Social Responsibility: A Scale Development. Journal of Business Ethics 15:1131-1140.

Singhapakdi, A., K. Karande, C. Rao, and S. Scott

2001a How Important Are Ethics and Social Responsibility? A Multinational Study of Marketing Professionals. European Journal of Marketing 35(1-2): 133-152.

Singhapakdi, A., J. Marta, C. Rao, and M. Curtis

$2001 \mathrm{~b}$ Is Cross-Cultural Similarity an Indicator of Similar Marketing Ethics? Journal of Business Ethics 32:55-68.

Spencer, B., and J. Butler Jr.

1987 Measuring the Relative Importance of Social Responsibility Components: A Decision Modeling Approach. Journal of Business Ethics 6:573577. 
Stanwick, P., and S. Stanwick

1998 The Relationship between Corporate Social Performance, and Organizational Size, Financial Performance, and Environmental Performance: An Empirical Examination. Journal of Business Ethics 17:195-204.

Stevens, B.

1997 Hotel Ethical Codes: A Content Analysis. International Journal of Hospitality Management 16:261-271.

2001 Hospitality Ethics: Responses from Human Resource Directors and Students to Seven Ethical Scenarios. Journal of Business Ethics 30:233-242.

Stevens, B., and A. Fleckenstein

1999 Comparative Ethics: How Students and Human-resources Directors React to Real-life Situations. Cornell Hotel and Restaurant Administration Quarterly 40(2):69-75.

Tsalikis, J., and D. Fritzsche

1989 Business Ethics: A Literature Review with a Focus on Marketing Ethics. Journal of Business Ethics 8:695-743.

Upchurch, R.

1998a Ethics in the Hospitality Industry: An Applied Model. International Journal of Contemporary Hospitality Management 10:227-233.

1998b A Conceptual Foundation for Ethical Decision Making: A Stakeholder Perspective in the Lodging Industry (USA). Journal of Business Research 17:1349-1361.

Upchurch, R., and S. Ruhland

1995 An Analysis of Ethical Work Climate and Leadership Relationship in Lodging Operations. Journal of Travel Research 34(2):36-42.

1996 The Organizational Bases of Ethical Work Climates in Lodging Operations as Perceived by General Managers. Journal of Business Research 15:10831093.

Vitell, S.J.

1986 Marketing Ethics: Conceptual and Empirical Foundation of a Positive Theory of Decision Making in Marketing Situations Having Ethical Content. Unpublished dissertation, Texas Tech University.

Vitell, S., K. Rallapalli, and A. Singhapakdi

1993a Marketing Norms: The Influence of Personal Moral Philosophies and Organizational Ethical Culture. Journal of the Academy of Marketing Science 21:331-337.

Vitell, S., S. Nwachukwu, and J. Barnes

1993b The Effects of Culture on Ethical Decision Making: An Application of Hofstede's Typology. Journal of Business Ethics 12:753-760.

Walle, A.

1995 Business Ethics and Tourism: From Micro to Macro Perspectives. Tourism Management 16:263-268.

Wheeler, M.

1995 Tourism Marketing Ethics: An Introduction. International Marketing Review 12:38-49.

Whitney, D.

1990 Ethics in the Hospitality Industry: With a Focus on Hotel Managers. International Journal of Hospitality Management 9(1):59-68.

Wight, $\mathrm{P}$.

1993 Ecotourism: Ethics or Eco-Sell. Journal of Travel Research 31(1):3-9.

Wong, S.

1998 Staff Job-related Ethics of Hotel Employees in Hong Kong. International Journal of Contemporary Hospitality Management 10(3):107-115.

Yaman, $\mathrm{H}$.

2003 Skinner's Naturalism as a Paradigm for Teaching Business Ethics: A Discussion from Tourism. Teaching Business Ethics 7:107-122.

Yeung, S., S. Wong, and B. Chan

2002 Ethical Beliefs of Hospitality and Tourism Students towards their School Life. International Journal of Contemporary Hospitality Management 14(4):183-192. 
Submitted 10 February 2004. Resubmitted 17 May 2005. Resubmitted 7 October 2005. Resubmitted 27 October 2005. Accepted 23 November 2005. Refereed anonymously. Coordinating Editor: Kadir Haji Din

Available online at www.sciencedirect.com

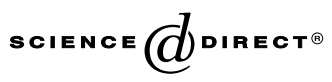

